\title{
Marcin Jędrzejczyk
}

Cracow University of Economics, Cracow, Poland

e-mail: jedrzejm@uek.krakow.pl

ORCID: 0000-0001-8959-3903

\section{Aleksander Klimek}

Cracow University of Economics, Cracow, Poland

e-mail: aleksander.klimek@o2.pl

ORCID 0000-0002-1454-0513

\section{POSSIBILITIES OF USING MANAGEMENT VARIABLE AND WAGE PRODUCTIVITY FOR BANKRUPTCY PREDICTION OF POLISH ENTERPRISES}

\section{MOŻLIWOŚCI WYKORZYSTANIA ZMIENNEJ \\ ZARZĄDZANIA I PRODUKTYWNOŚCI PRACY \\ DO PREDYKCJI BANKRUCTWA POLSKICH PRZEDSIECIORSTW}

DOI: $10.15611 /$ pn.2019.4.07

JEL Classification: G33

Summary: The risk of bankruptcy of an enterprise is inevitably inscribed in running a business. This risk should be managed effectively in order to avoid negative consequences associated with the bankruptcy of an entity. This article will present the economic and legal causes of bankruptcy, followed by its negative and positive effects. In connection with this topic, the authors will discuss the concept of the microeconomic wage productivity and the management variable in the context of their importance in an enterprise. As an extension of previous studies by one of the authors, an attempt will be made to determine the possibility of applying the microeconomic wage productivity and the management variable as a supplement of the bankruptcy risk analysis of enterprises that are suppliers to the automotive industry in Poland.

Keywords: causes of bankruptcy, consequences of bankruptcy, wage productivity, management variable.

Streszczenie: Ryzyko bankructwa przedsiębiorstwa jest nieodzownie wpisane w prowadzenie działalności gospodarczej. Ryzykiem tym należy skutecznie zarządzać, by uniknąć negatywnych skutków związanych z bankructwem jednostki. W niniejszym artykule przedstawione zostaną ekonomiczne oraz prawne przyczyny upadłości, a w dalszej kolejności negatywne, a także pozytywne jej skutki. W powiązaniu z tym tematem autorzy prezentują koncepcję 
mikroekonomicznej produktywności pracy oraz zmiennej zarządzania w kontekście ich znaczenia w przedsiębiorstwie. Jako rozszerzenie wcześniejszych badań jednego z autorów zostanie także podjęta próba określenia możliwości zastosowania mikroekonomicznej produktywności pracy oraz zmiennej zarządzania jako rozszerzenia analizy ryzyka upadłości przedsiębiorstw stanowiących dostawców dla branży motoryzacyjnej na terenie Polski.

Słowa kluczowe: przyczyny bankructwa, skutki upadłości, produktywność pracy, zmienna zarządzania.

\section{Introduction}

Due to the economic, technological and social changes occurring worldwide in the global economy, entrepreneurs become increasingly aware of the growing risk of crisis situations which may occur as part of running a business and, in extreme cases, may lead to the bankruptcy of an enterprise.

An underlying cause of the crisis is the naturally inseparable quality of the global economy, namely its cyclicity, i.e. the occurrence of business cycles which are based on successive periods of economic prosperity and economic collapse. Nowadays the ongoing advancement of civilisation has undoubtedly a great impact on generating crisis situations and is reflected, among other things, in the gradual decline of industrial economies and the move towards virtualised economy, wikinomics and macrowikinomics. Its accompanying element is the financialization of the economy with a visible separation of the financial sector and cash flow from the actual production processes in the economy. This process and the previous experience of global economic history lead us to expect that the frequency of crisis situations affecting enterprises will grow increasingly [Collective work 2013].

When accepting the challenge of running a business, each entrepreneur must take into account the existence of the risk associated with the lack of success on the market. The lack of a competitive product/service (in a competitive market), excessively high prices or costs exceeding the generated margin constitute the prerequisites indicating the risk of failure. Only those enterprises that are able to adapt to a changing economy quickly and effectively are guaranteed to stay on the market for longer. Bankruptcies of enterprises may be considered as some form of self-regulation of the economy, eliminating from the market the weaker parties, operating ineffectively and not able to cope with strong competition [Collective work 2013].

\section{Legal and economic causes and consequences of bankruptcy}

\section{Insolvency and bankruptcy: economic and legal conditions}

Bankruptcy and insolvency of an enterprise are synonyms. Although using these two terms for describing the same process concerning enterprises is customarily 
accepted, in fact there is a subtle difference between these two concepts. Insolvency is an economic term describing the inability of an enterprise to settle its maturing cash liabilities ${ }^{1}$, and a situation in which the sum of assets does not cover the total liabilities of an entity. This is a state of an enterprise resulting in the impossibility of continuing operation in such a way that would lead to the re-establishment of its competitive capacity, profitability, liquidity and solvency without external assistance (e.g. in the form of recapitalisation, write-off or restructuring of a debt). Thus, from an economic point of view, an entity which continues running a business after the occurrence of the above-mentioned insolvency conditions is also an insolvent.

Since the introduction of the Bankruptcy Act in 2016, legal bankruptcy can be defined as a set of norms and procedures regulated by the bankruptcy law. From the legal point of view, insolvency is now the most frequently appearing concept. The provisions of the aforementioned Act regulate that a necessary condition for a bankruptcy declaration of a given entity must be its insolvency. Insolvency is clearly defined in Article 11 of the Bankruptcy Act, where the Legislator states that the debtor becomes insolvent when they lose the ability to perform their due financial obligations. Article 11.1 stipulates that the time limit to determine insolvency is a period of three months. In the case of legal persons (and organizational units having a legal personality under other acts), insolvency in the legal sense is also imposed in a situation when the entity's financial obligations exceed the value of its assets for a period of at least 24 months.

Although the content of the Bankruptcy Act has significantly modified the existing grounds for the debtor's insolvency, it can still be generally defined as:

- loss of liquidity;

- excessive debt [Adamus 2019].

On 1 January 2016, the provisions on bankruptcy proceedings were repealed from the bankruptcy and reorganization law, and introduced to the separate Restructuring Act. This resulted in the name being changed to the "Bankruptcy Act" [Witosz, Janik 2015].

The creation of a separate restructuring law was aimed at enabling the restructuring of the debtor's entity in order to protect against its liquidation. Such action is meant to enable the enterprise to continue its earning activity, to preserve jobs and to prevent negative financial consequences. Prior to 2016, such actions were possible owing to the provisions of the Bankruptcy and Reorganization Law, namely the provisions giving the possibility of conducting bankruptcy proceedings with the potential of concluding an arrangement [Sarna 2016].

${ }^{1}$ Art. 11 ust. 1 Ustawy z dnia 28 lutego 2003 r. Prawo upadłościowe tekst jedn. Dz.U 2015, poz. 233 ze zm. w brzmieniu Ustawy z dnia 15 maja 2015 Prawo restrukturyzacyjne, Dz.U. 2015, poz. 978 ze zm. 


\section{Causes of bankruptcy among enterprises in Polish conditions}

There are many factors affecting the risk of insolvency of an enterprise and, as mentioned above, their number is growing increasingly in a dynamically changing global economy. Elements that would prejudice the continuation of economic activity can be divided into financial and non-financial risks.

Financial risks include, among other things:

- worsening financial results of an entity (significant falls in profits and the emergence or continuation of net loss);

- significant drops in revenues from sales;

- decline in liquidity (the causes may include, for instance, the emergence of irrecoverable receivables or the ones difficult to recover, increase in liabilities);

- increase in short-term debt with respect to credits and loans;

- using more expensive tools for the improvement of liquidity (e.g. granting cash discounts);

- worsening of inventory aging, an update of the carrying value of non-financial assets;

- sale of assets;

- persistent negative cash flows from operating activities.

Non-financial risks may include:

- legal causes - unfavourable legislative changes (e.g. tax increase, import duties);

- lack of market risk management, not using insurance of receivables;

- judicial proceedings;

- difficulties on a labour market;

- disruption of a supply chain due to the loss of critical suppliers;

- technological changes;

- evolution of the market, loss of selling markets.

Economic causes of bankruptcy may be in turn divided into endogenous (microeconomic, on the part of an enterprise) and exogenous (macroeconomic). Macroeconomic causes of insolvency include three groups:

- industry causes (e.g. strong competition);

- domestic/national factors (recession of a national economy, weakness or strength of a local currency, legal and institutional changes);

- worldwide/global causes (economic and political situation on a global scale). It is important to note that the causes of bankruptcy may vary depending on the industry. They also change over time, which was confirmed by the research conducted in Poland at the turn of the $20^{\text {th }}$ and $21^{\text {st }}$ century [Boratyńska 2009].

\section{Positive and negative consequences of bankruptcy}

The most important negative aspects of insolvency and subsequent bankruptcy (when the bankruptcy is adjudicated by a court) include the emergence of additional costs. These are the financial costs related to the losses of shareholders, creditors and 
lenders, the costs borne by trade creditors on account of the unsettled liabilities of a bankrupt. They are also social costs resulting from the insolvency of an entity and reflected, for example, in the growing rate of unemployment in a local community or a region (depending of the size of an enterprise - the bigger the enterprise going bankrupt, the greater the negative effect on the economy). Finally, there are the legal and judicial costs arising from the continuation of bankruptcy proceedings. In fact the bankruptcy of a given enterprise affects to a greater or lesser extent all stakeholders of an entity.

Should an enterprise be on the brink of bankruptcy, the continuation of business activities entails strong negative effects. The protests of employees, subsidising unprofitable entities, undertaking a series of restructuring measures for the benefit of such entities, are all common situations. However we must come to recognise that the bankruptcy of non-promising enterprises, deprived of the opportunity to get back on track of generating income for the shareholders, is not an unequivocally negative phenomenon. Eliminating such entities from the market is a necessity of some kind, a consequence of well-functioning market mechanisms. This process is not an independent one - in Poland it is based on the bankruptcy and reorganisation law. The legal regulations and procedures associated with the institution of bankruptcy proceedings are also mechanisms that partially protect and support the creditors of an enterprise at risk of going bankrupt. They have an impact on minimising the negative effect of a bankrupt on the whole environment [Mioduchowska-Jaroszewicz, Szczepkowska 2016].

\section{The concept of microeconomic wage productivity and management variable and their importance in an enterprise}

As the author points out, a production function does not correspond to the essence of production factors' arrangement in the process of creating the value of service or the final product [Jędrzejczyk 2013]. Therefore it is worth mentioning the equation of economic activity function derived from the accounting system in which accumulating costs is of major importance and, as a result, has a useful effect in the form of added value attributed to a product [Barburski, Dobija 2007].

The analytical form of an economic activity function presented by M. Dobija and M. Jędrzejczyk in 2007, resulting from the accounting accumulation of production costs takes the form of (1) [Dobija, Jędrzejczyk 2013]:

$$
\text { Production cost }=(W+M-R)=(W+z \cdot A-S \cdot A),
$$

where: $W$ - working costs, $A$ - assets valued in a balance sheet of an enterprise, $M$ - costs generated as a result of usufruct and depreciation of assets, $R$-natural losses as a result of production process. Through the introduction 
of relations $M / A=\mathrm{z}$ and $R / A=\mathrm{s}$ it is possible to determine the value of production volume $(P)$ expressed in a market value according to equation (2):

$$
P=(W+z \cdot A-s \cdot A)(1+r)(1+I),
$$

where: $P$ - value of production volume expressed in market prices, $z$ - annual asset turnover index, $s$ - losses of assets in a production process, $r$ - average increase of historic value to a market value, $I$ - additional value created as a result of intellectual capital existing in an enterprise and exceeding average market value growth in the remaining enterprises of a given industry.

After applicable transformations it is possible to create an equation which describes production $(P)(3)$ :

$$
P=W \cdot[1+A / W \cdot(z-s)](1+r)(1+I) .
$$

Since $W$ variable is a derivative of human capital, one may successfully apply the equation $W=u \cdot H$, where: u represents a degree of payment for employees' work and $H$ is an accumulated human capital value of all workers employed in an organisation. By making adequate substitutions one may reach equation (4):

$$
P=W \cdot[1+A / H \cdot(z-s) / u](1+r)(1+I) .
$$

By using the relation $1+x \approx e^{x}$ for values close to zero, a production function may be written with equation (5):

$$
P=W e^{r+I}[1+A / H \cdot[(z-s) / u]]=W \cdot Q,
$$

where $\mathrm{Q}$ means microeconomic wage productivity. Wage productivity resulting from the nature of production process is thus a dimensionless quantity and, as a functional relationship, a function of several variables such as technical work equipment, asset turnover, coefficient of risk costs, the amount of remuneration for the work done and the capacity to generate market value, which may be written in the following manner:

$$
Q=\frac{P}{W}=e^{r+I}\left[1+\frac{A}{H} \cdot \frac{z-s}{u}\right] .
$$

Therefore, wage productivity $(Q)$ depends on the capacity to generate market value $(r+\mathrm{I})$, technical work equipment $(\mathrm{A} / \mathrm{H})$, asset turnover $(z)$, coefficient of risk costs $(s)$ and the amount of remuneration for the work done $(u)$.

Wage productivity $(Q)$ in a microeconomic sense is a multiplier of working costs which represents the production volume per PLN 1 engaged in the process of work production. There is thus a functional relationship between the structure of the presented variables and the production expressed in market prices. Furthermore, production assessment in figures may be obtained using the easiest method - dividing annual production in sales price by working costs. The simplicity of the calculations is combined with theoretical complexity. 
Work production $(Q)$ is easy to interpret in the management conditions of an enterprise. Everyone intuitively understands that the possibility of controlling dynamically this dimensionless index is an advantage. All in all, it is possible to say that the higher the $Q$, the better the enterprise prospers. In a dynamic sense, the increase of this index is desired over time and inter-branch comparisons can be based on the $Q$ value. In light of the foregoing considerations, wage productivity $(Q)$ and management variable will be used in an attempt to assess the bankruptcy risk.

The microeconomic dimension of wage productivity $(Q)$ enables explaining the essence of this variable from the point of view of an enterprise manufacturing products or providing services. However, it should be noted that the defined microeconomic wage productivity for the purposes of this study is not identical to the understanding of productivity by Balassa and Samuelson, who attempt to apply differences in productivity in order to explain the weaknesses in the theory of the purchasing power of money in the long term. Wage productivity on a micro scale concerns the functioning of an enterprise and points to the tangible results of its activities in a competitive environment.

Management variable $(M)$ is a derivative of wage productivity coming from an additive function of economic activity. On the basis of previous observations, it is possible to introduce a production model with a synthetic management variable $(M)$. Its formalised form is as follows:

$$
P=W \cdot Q=W e^{r+I}\left\{1+\frac{A}{H} \cdot \frac{z-S}{u}\right\} \cong W \exp \frac{A \cdot M}{H} .
$$

$M$ variable integrates the interactions of all the aforementioned variables marked in lowercase letters, that is: asset turnover $(z)$, degree of payment for work $(u)$, losses $(s)$, profitability $(r)$ and intellectual capital $(I)$ if such exists. These variables are connected with the ongoing decisions of the management. Management variable $(M)$ may be calculated out of this model by determining human capital $(H)$ out of the $L=p \cdot H$ relationship, where $p=0.08$ constitutes the risk premium and $L$ determines the volume of working costs resulting from the level of basic salary.

$$
P=W \exp \frac{p \cdot A \cdot M}{L} \text {, so } M=\frac{L \cdot \ln (P / W)}{p \cdot A} .
$$

The management variable is directly proportional to the logarithm of wage productivity and inversely proportional to the capital intensity measured with indices $A / L$.

Therefore the management variable is closely related to wage productivity, which includes the majority of the crucial variables characterising the economic achievements of an enterprise. As shown above, the $\mathrm{Q}$ index integrates a number of five variables, whereas the management variable additionally includes basic salaries, risk premiums and the capital intensity of production processes. This synthetic 
measure does not include the repayment of receivables on credit sales and control of bad debts.

An increase in the value of management variable $(M)$ over time is a strong indicator of the good and improving state of the management and the entire enterprise, whereas its gradual decrease, as it seems, may be an indicator of the economic entity's bankruptcy. This type of empirical analysis will be a subject of interest in further considerations.

\section{An attempt to apply MPP and $\mathrm{ZZ}$ in a predictive analysis of insolvencies among enterprises that are suppliers to the automotive industry}

Microeconomic wage productivity is applicable in many aspects of managing economic entities. In this study an attempt was made to verify microeconomic wage productivity and management variable as supplementary tools in the bankruptcy risk analysis among manufacturing companies in Polish conditions. The research conducted by A. Klimek as a co-author, aimed at indicating the possibility of the complementary use of discriminant analysis and ratio analysis in the bankruptcy risk analysis among Polish manufacturing companies that are suppliers to the automotive industry, constituted the groundwork for this analysis. Together with A. Moskała, he examined 30 enterprises, determining the level of bankruptcy risk as part of the authorial rating.

The authors of the article analysed the research sample presented above once more. It turned out that for 20 out of 30 analysed enterprises, data integrity enables the indication of working costs and, subsequently, the calculation of wage productivity level. The indices were calculated for the five years for which financial data were available, whereas for some enterprises it was possible to indicate productivity only for three accounting periods. The results are set out in Table 2.

Then the convergence of horizontal analysis results (wage productivity trend) was analysed along with the classes of risk indicated as part of the research conducted by A. Klimek and A. Moskała. According to the research hypothesis, for manufacturing companies with the highest risk of bankruptcy, the wage productivity trend will be less beneficial than for enterprises characterised by a good financial condition (in many cases this may be a decreasing trend).

The research confirmed the validity of the hypothesis - for all three enterprises indicated within the framework of previous research as the most endangered with bankruptcy, an unfavourable trend of microeconomic wage productivity index was noted. In the case of two enterprises the index showed a highly declining trend, whereas the third enterprise demonstrated a relatively low wage productivity against the whole population in a given period. The results are presented in the Fig. 1. 
Table 1. Classes of risk attributed to the analysed enterprises

\begin{tabular}{|c|c|c|c|c|c|c|c|c|c|c|c|c|c|}
\hline \multicolumn{4}{|c|}{ RATING } & \multicolumn{7}{|c|}{ GROUP 1} & \multicolumn{3}{|c|}{ GROUP 2} \\
\hline $\begin{array}{c}\text { Enterprise } \\
\text { number }\end{array}$ & $\begin{array}{c}\text { Numerical } \\
\text { rating }\end{array}$ & code & Bankruptcy Risk & CR & DR & NDR & $\begin{array}{l}\text { ROS, } \\
\text { ROA, } \\
\text { ROE }\end{array}$ & $\begin{array}{c}\text { Net } \\
\text { Working } \\
\text { Capital }\end{array}$ & $\begin{array}{c}\text { CF } \\
\text { structure }\end{array}$ & Total & $\begin{array}{l}\text { Poznan } \\
\text { model }\end{array}$ & $\begin{array}{l}\text { Hołda } \\
\text { model }\end{array}$ & Total \\
\hline 1 & 9 & $A A$ & Minimal risk & 0 & 0 & 0 & 0 & 0 & 0 & 0 & 익 & 0 & 0 \\
\hline 2 & 9 & $\mathrm{AA}$ & Minimal risk & 0 & 0 & 0 & 0 & 0 & 0 & 0 & 0 & 0 & 0 \\
\hline 3 & 4 & C & Increased risk & 1 & 1 & 0 & 0 & 1 & 0 & 3 & 0 & 1 & 1 \\
\hline 4 & 8 & A & Very low risk & 1 & 0 & N/A & 0 & 0 & 0 & 1 & 0 & 0 & 0 \\
\hline 5 & 9 & $A A$ & Minimal risk & 0 & 1 & 0 & 0 & 요 & 0 & 0 & 요 & 0 & 0 \\
\hline 6 & 7 & BB & Low risk & 0 & 1 & 0 & 0 & 1 & 0 & 2 & 이 & 0 & 0 \\
\hline 7 & 8 & A & Very low risk & 0 & 요 & 0 & 0 & 1 & 0 & 1 & 운 & 0 & 0 \\
\hline 8 & 7 & $\mathrm{BB}$ & Low risk & 1 & 0 & 0 & 0 & 1 & 0 & 2 & 0 & 0 & 0 \\
\hline 9 & 9 & $A A$ & Minimal risk & 0 & 0 & 0 & 0 & 0 & 0 & 0 & 이 & 0 & 0 \\
\hline 10 & 9 & $A A$ & Minimal risk & 0 & 0 & $\mathrm{~N} / \mathrm{A}$ & 0 & 0 & 0 & 0 & 0 & 0 & 0 \\
\hline 11 & 9 & $A A$ & Minimal risk & 0 & 0 & 0 & 0 & 0 & 0 & 0 & 이 & 0 & 0 \\
\hline 12 & 8 & A & Very low risk & 익 & 이 & 0 & 0 & 1 & 0 & 1 & 인 & 0 & 0 \\
\hline 13 & 9 & $A A$ & Minimal risk & 0 & 0 & 0 & 0 & 0 & 0 & 0 & 0 & 0 & 0 \\
\hline 14 & 3 & DD & High risk & 1 & 0 & 1 & 1 & 1 & 0 & 4 & 0 & 1 & 1 \\
\hline 15 & 8 & A & Very low risk & 0 & 인 & N/A & 1 & 요 & 0 & 1 & 0 & 0 & 0 \\
\hline 16 & 9 & $A A$ & Minimal risk & 0 & 0 & N/A & 0 & 0 & 0 & 0 & 0 & 0 & 0 \\
\hline 17 & 9 & $A A$ & Minimal risk & 0 & 요 & 0 & 0 & 요 & 0 & 0 & 0 & 0 & 0 \\
\hline 18 & 8 & A & Very low risk & 1 & 인 & 0 & 0 & 인 & 0 & 1 & 이 & 0 & 0 \\
\hline 19 & 3 & DD & High risk & 1 & 1 & 1 & 0 & 1 & 0 & 4 & 이 & 1 & 1 \\
\hline 20 & 9 & $A A$ & Minimal risk & 0 & 0 & $\mathrm{~N} / \mathrm{A}$ & 0 & 0 & 0 & 0 & 이 & 0 & 0 \\
\hline 21 & 8 & A & Very low risk & 0 & 1 & N/A & 0 & 0 & 0 & 1 & 이 & 0 & 0 \\
\hline 22 & 9 & $A A$ & Minimal risk & 0 & 0 & 0 & 0 & 0 & 0 & 0 & 인 & 0 & 0 \\
\hline 23 & 8 & A & Very low risk & 0 & 0 & 0 & 1 & 0 & 0 & 1 & 0 & 0 & 0 \\
\hline 24 & 9 & $A A$ & Minimal risk & 0 & 0 & 0 & 0 & 0 & 0 & 0 & 이 & 0 & 0 \\
\hline 25 & 9 & $A A$ & Minimal risk & 0 & 0 & 0 & 0 & 0 & 0 & 0 & 이 & 0 & 0 \\
\hline 26 & 9 & $A A$ & Minimal risk & 0 & 0 & 0 & 0 & 0 & 0 & 0 & 이 & 0 & 0 \\
\hline 27 & 9 & $A A$ & Minimal risk & 0 & 0 & 0 & 0 & 0 & 0 & 0 & 0 & 0 & 0 \\
\hline 28 & 9 & $A A$ & Minimal risk & 인 & 이 & 0 & 0 & 0 & 0 & 0 & 0 & 0 & 0 \\
\hline 29 & 8 & A & Very low risk & 익 & 1 & 0 & 0 & 0 & 0 & 1 & 인 & 0 & 0 \\
\hline 30 & 9 & $A A$ & Minimal risk & 0 & 0 & N/A & 0 & 요 & 0 & 0 & 이 & 0 & 0 \\
\hline
\end{tabular}

Source: elaboration A. by Klimek, as part of research conducted with A. Moskała. 


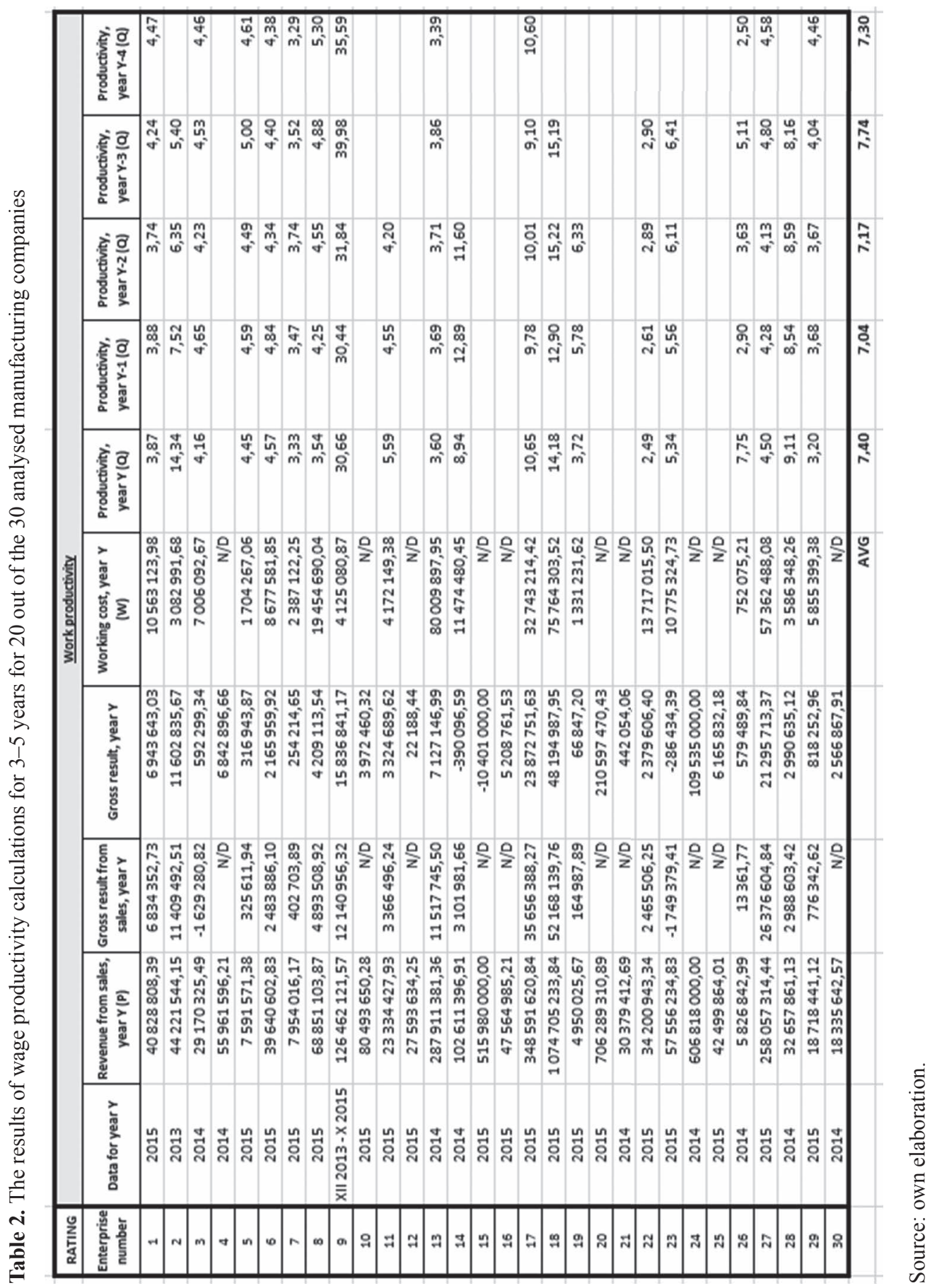




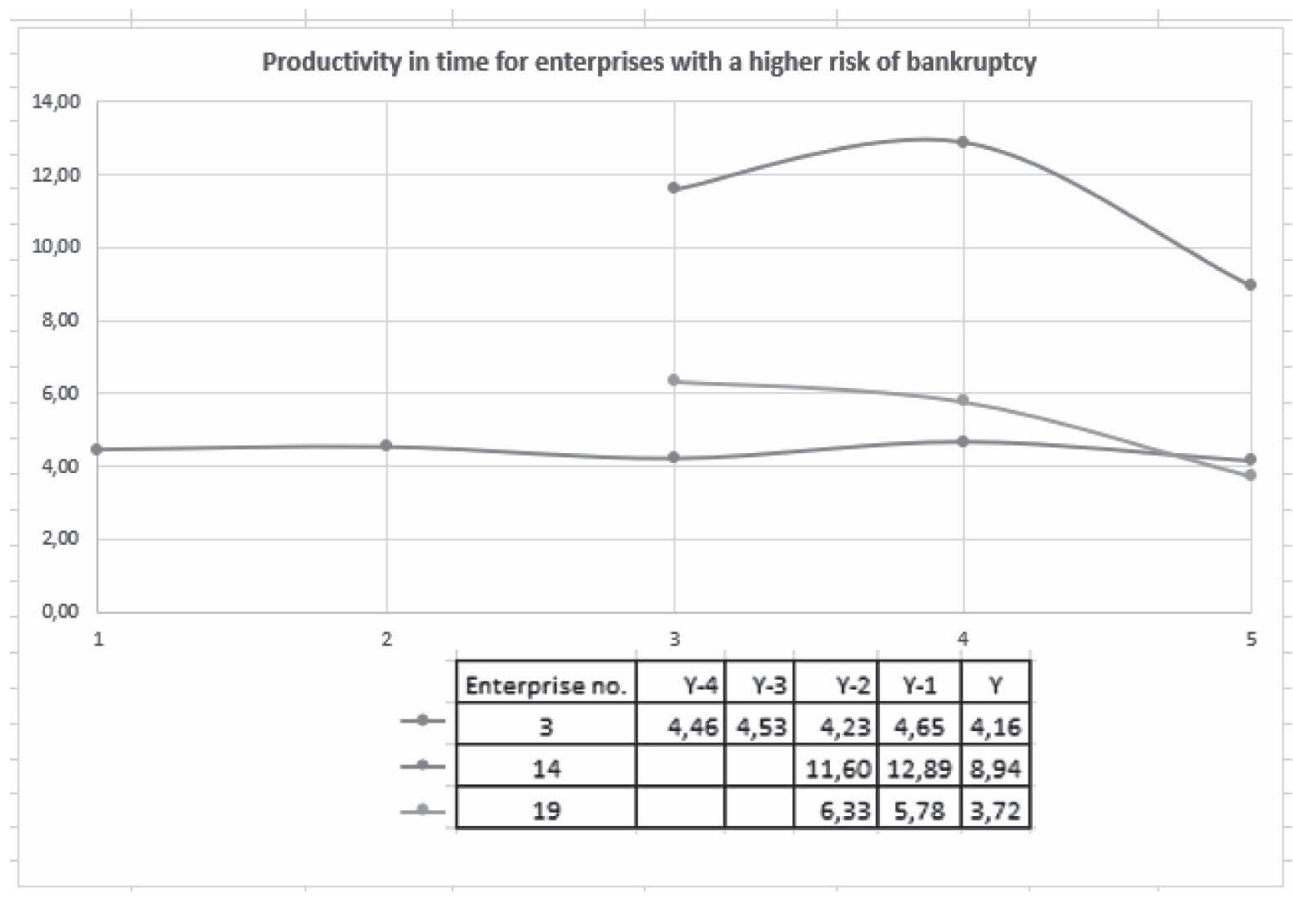

Fig. 1. Wage productivity trend for enterprises considerably endangered with bankruptcy Source: own elaboration.

In order to ensure the completeness of the analysis, the authors of the research addressed the results of the management variable index for the analysed population. The management variable was determined on the basis of the equation:

$$
M=\frac{L \cdot \ln (P / W)}{p \cdot A} .
$$

An interest rate equal to $8 \%$ was assumed as $p$ (risk premium), where the position of remuneration from profit and loss account multiplied by 0.86 coefficient (an assumption that on average $14 \%$ of the remuneration amount will constitute a bonus factor in the population) was defined as $L$.

The results are presented in Table 3.

The analysis of management variable results for the last 3-5 years, conducted for entities with a higher risk of bankruptcy determined in previous research, showed an indeterminate trend. 
Table 3. The results of management variable calculations for 3-5 years for 20 out of the 30 analysed manufacturing companies

\begin{tabular}{|c|c|c|c|c|c|}
\hline \multirow[b]{2}{*}{$\begin{array}{c}\text { Enterprise } \\
\text { no. }\end{array}$} & \multicolumn{5}{|c|}{ Manasement variable } \\
\hline & $\begin{array}{c}\text { Management varisble, } \\
\text { year } Y(Q)\end{array}$ & $\begin{array}{c}\text { Manasement variable, } \\
\text { year } Y-1(Q)\end{array}$ & $\begin{array}{c}\text { Mansagement variable, } \\
\text { year } Y-2 \text { (1) }\end{array}$ & $\begin{array}{c}\text { Manasement varibble, } \\
\text { year } Y-3 \text { (Q) }\end{array}$ & $\begin{array}{c}\text { Manasement variable, } \\
\text { year } Y-4 \text { (Q) }\end{array}$ \\
\hline 1 & 2,51 & 2,53 & 2,40 & 3,01 & 3,37 \\
\hline 2 & 3,38 & 5,21 & 4,53 & 3,35 & \\
\hline 3 & 1,61 & 2,15 & 1,82 & 1,62 & 3,18 \\
\hline \multicolumn{6}{|l|}{4} \\
\hline 5 & 9,55 & 11,14 & 10,31 & 9,76 & 9,22 \\
\hline 6 & 1,73 & 1,43 & 1,37 & 2,08 & 0,99 \\
\hline 7 & 3,82 & 3,40 & 3,61 & 2,62 & 2,55 \\
\hline 8 & 3,50 & 3,13 & 4,35 & 4,53 & 4,87 \\
\hline 9 & 0,71 & 0,77 & 2,38 & 2,46 & 2,02 \\
\hline \multicolumn{6}{|l|}{10} \\
\hline 11 & 2,80 & 2,46 & 1,36 & & \\
\hline \multicolumn{6}{|l|}{12} \\
\hline 13 & 4,90 & 4,31 & 4,99 & 4,91 & 4,10 \\
\hline 14 & 2,67 & 3,21 & 1,10 & & \\
\hline \multicolumn{6}{|l|}{15} \\
\hline \multicolumn{6}{|l|}{16} \\
\hline 17 & 4,88 & 4,88 & 5,10 & 5,57 & 5,19 \\
\hline 18 & 3,50 & 3,74 & 3,65 & 4,04 & \\
\hline 19 & 2,47 & 2,29 & 2,29 & & \\
\hline \multicolumn{6}{|l|}{20} \\
\hline \multicolumn{6}{|l|}{21} \\
\hline 22 & 4,77 & 5,33 & 5,51 & 6,09 & \\
\hline 23 & 5,33 & 5,35 & 5,05 & 4,69 & \\
\hline \multicolumn{6}{|l|}{24} \\
\hline \multicolumn{6}{|l|}{25} \\
\hline 26 & 3,40 & 4,12 & 4,62 & 3,91 & 6,86 \\
\hline 27 & 5,74 & 5,37 & 5,45 & 4,99 & 5,50 \\
\hline 28 & 5,32 & 4,99 & 5,15 & 5,36 & \\
\hline 29 & 3,55 & 5,08 & 4,89 & 5,02 & 4,96 \\
\hline 30 & & & & & \\
\hline
\end{tabular}

Source: own elaboration.

Such results of the management variable analysis may be associated with the small sample size of entities with a higher risk of bankruptcy for which the variable was interpreted. The limited availability of financial data necessary for conducting a detailed horizontal analysis could also have an impact on the indeterminate nature of a trend. Despite limitations during the research, the authors postulate the validity of determining the management variable, along with the microeconomic 


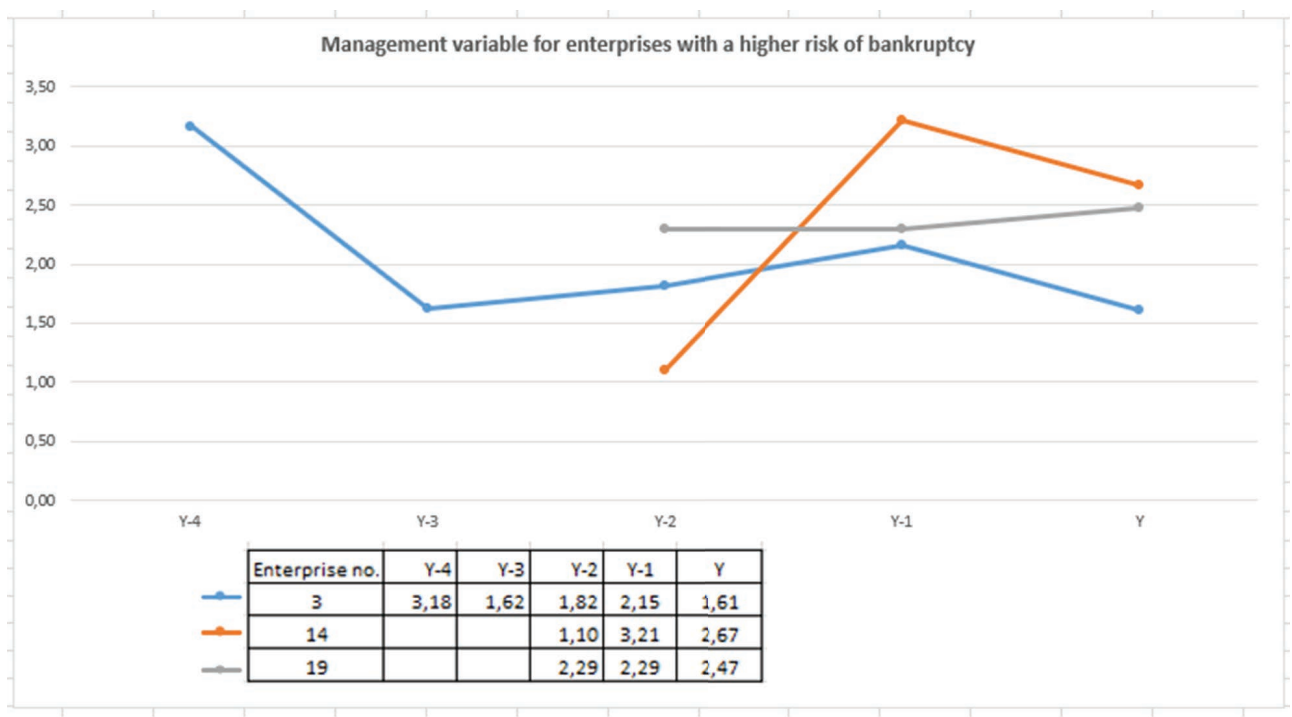

Fig. 2. Management variable trend for enterprises considerably endangered with bankruptcy

Source: own elaboration.

wage productivity, as a supplementary element of bankruptcy risk analysis among manufacturing companies.

\section{Conclusions and recommendations for economic activity}

Wage productivity as a dimensionless index is characterised by many advantages. First of all, the simplicity of the calculations; secondly, the relatively easy availability of calculation data in a documentation prepared obligatorily according to the Accounting Act and International Financial Reporting Standards and, above all, the simple interpretation of the index values, the only standard of which is the preceding value. From this point of view, an analysis of the dynamics of microeconomic wage productivity may lead to binding conclusions, which was proved in the empirical research conducted as part of this study in connection with the automotive industry. It seems reasonable to say that one should simultaneously conduct the control of financial indices, calculation results based on discrimination models, and, complementarily, the management variable and microeconomic wage productivity trends. The authors of many recent studies have demonstrated the pragmatic possibilities of applying the microeconomic wage productivity and the management variable in the process of controlling profit and profitability, designing a system of bonus payments and work evaluation of the entity's management board. The result of the conducted research is the possibility of the credible usage of microeconomic 
wage productivity in prospective bankruptcy evaluation, which is yet another proof of the thesis stating that wage productivity, no matter whether on a micro or macro scale, should constitute the main index in the economy. Now, the main weakness of the conducted research is the number of enterprises chosen to study a single branch of Polish companies as the basis of research and its lack of representativeness. Hence the future of the conducted research is gathering a bigger database of Polish companies to confirm the role of microeconomic wage productivity and management variable in bankruptcy prediction. Both coefficients can constitute the basis for designing new bankruptcy models, thus strengthening the financial analysis indexes.

\section{Bibliography}

Adamus R., 2019, Prawo upadłościowe. Komentarz, Wydawnictwo C.H. Beck, Warszawa.

Barburski J., Dobija M., 2007, Produktywność pracy w aspekcie makro- $i$ mikroekonomicznym, [w:] Dudycz T., Tomaszewicz Ł. (eds.), Efektywność - rozważania nad istota i pomiarem, Wydawnictwo Uniwersytetu Ekonomicznego we Wrocławiu.

Boratyńska K., 2009, Przyczyny upadłości przedsiębiorstw w Polsce, Ekonomiczne Problemy Usług, no. 39.

Collective work 2013, Bankructwa przedsiębiorstw. Efektywność postępowań upadtościowych, Biuletyn Polskiego Towarzystwa Ekonomicznego, no. 1(60).

Dobija M., Jędrzejczyk M., 2013, Production function in the cost accounting approach and managerial applications, Zeszyty Teoretyczne Rachunkowości, SKwP, vol. 72(128), pp. 49-62.

Jędrzejczyk M., 2013, Kurs walutowy a ekwiwalentna translacja wartości ekonomicznych, Difin, Warszawa.

Mączyńska E., 2015, Bankructwa, upadłości i procesy naprawcze przedsiębiorstw. Wybrane aspekty regulacyjne, Oficyna Wydawnicza, Szkoła Główna Handlowa w Warszawie.

Mioduchowska-Jaroszewicz E., Szczepkowska M., 2016, Pozytywne i negatywne skutki upadtości, Studia i Prace WNEiZ US, no. 43/1.

Nowak E., Nieplowicz M., 2014, Modele zarządzania kosztami i dokonaniami, Prace Naukowe Uniwersytetu Ekonomicznego we Wrocławiu, no. 343.

Sarna M., 2016, Prawo restrukturyzacyjne. Z komentarzem, Wydawnictwo Wiedza i Praktyka, Warszawa.

Tokarski K., 2012, Charakterystyka podstawowych rodzajów upadłości firm w edukacji przedsiębiorczości, Przedsiębiorczość - Edukacja, Wyższa Szkoła Bankowa w Toruniu.

Ustawa z dnia 28 lutego 2003 r. Prawo upadłościowe, tekst jedn. Dz.U 2015, poz. 233 ze zm. w brzmieniu Ustawy z dnia 15 maja 2015 r. Prawo restrukturyzacyjne, Dz.U. 2015, poz. 978 ze zm.

Witosz A.J., Janik E., 2015, Od restrukturyzacji do likwidacji spótek handlowych, Wydawnictwo Uniwersytetu Ekonomicznego w Katowicach, Katowice. 